\title{
Bacillus subtilis ORF yybQ encodes a manganese-dependent inorganic pyrophosphatase with distinctive properties: the first of a new class of soluble pyrophosphatase?
}

\author{
Tom W. Young, Nicholas J. Kuhn, Albert Wadeson, Simon Ward, \\ Dan Burges and G. Dunstan Cooke
}

\author{
Author for correspondence: Tom W. Young. Tel: +44 121414 5437. Fax: +44 1214143982. \\ e-mail: t.w.young@bham.ac.uk
}

School of Biochemistry, The University of

Birmingham, Edgbaston, Birmingham B15 2TT, UK

\begin{abstract}
The N-terminal 15 amino acids of the major protein associated with inorganic pyrophosphatase activity in Bacillus subtilis WB600 are identical to those of $B$. subtilis ORF yybQ. This ORF was amplified from B. subtilis WB600 DNA by PCR and cloned into an overexpression vector in Escherichia coli. Induction of overexpression produced a soluble protein of $34000 \mathrm{Da}$ by SDS-PAGE and by matrix-assisted laser desorption and ionization mass spectrometry. The overexpressed protein had a high specific activity for the hydrolysis of magnesium pyrophosphate, and was specifically and reversibly activated by $\mathrm{Mn}^{2+}$ ions. These properties are identical to those of inorganic pyrophosphatase purified from B. subtilis WB600. No significant similarity was found between the derived sequence of the $B$. subtilis yybQ-encoded protein and published sequences of identified inorganic pyrophosphatases of Eukarya, Bacteria or Archaea domains. However, there is significant similarity to three putative proteins of unknown function from the archaea Methanococcus jannaschii and Archaeoglobus fulgidus, and from Streptococcus gordonii. The genomes of B. subtilis, M. jannaschii and A. fulgidus do not contain sequences similar to those of hitherto known soluble inorganic pyrophosphatases. The present findings, together with a survey of the properties of inorganic pyrophosphatases from 38 different sources, suggest that the $B$. subtilis yybQencoded protein is the first fully characterized member of a new class of inorganic pyrophosphatase.
\end{abstract}

Keywords: pyrophosphatase, bacteria, Bacillus subtilis, manganese, enzyme classification

\section{INTRODUCTION}

Soluble inorganic pyrophosphatase $\left(\mathrm{PP}_{\mathrm{i}}\right.$ ase; $\mathrm{EC}$ 3.6.1.1) is an enzyme found in nearly all living cells, where it removes the pyrophosphate $\left(\mathrm{PP}_{\mathrm{i}}\right)$ generated by many important biosynthetic pathways. Since $\mathrm{PP}_{\mathrm{i}}$ is usually produced in near-equilibrium reactions, the action of $\mathrm{PP}_{\mathrm{i}}$ ase serves to pull the equilibrium over in favour of synthesis. In keeping with its central role in metabolism, $\mathrm{PP}_{\mathrm{i}}$ ase has been shown to be essential for the growth of Escherichia coli (Chen et al., 1990) and for

Abbreviations: MALDI-MS, matrix-assisted laser desorption and ionization mass spectrometry; $\mathrm{PP}_{\mathrm{i}}$ ase, inorganic pyrophosphatase. yeast mitochondrial function (Lundin et al., 1991). $\mathrm{PP}_{\mathrm{i}}$ ases have been studied and purified from a number of eukarya and bacteria, and from one archaeon. Although two common subunit sizes are discerned, about $20000 \mathrm{Da}$ for prokaryotes and about 28000-35000 Da for most eukaryotes, there are appreciable sequence similarities between all of them (Cooperman et al., 1992; Meyer et al., 1995). Furthermore, these enzymes apparently hydrolyse $\mathrm{Mg} . \mathrm{PP}_{\mathbf{i}}$ without need for prior activation by other agents. Recently, following the early work by Tono \& Kornberg (1967b), the PP ${ }_{\mathrm{i}}$ ase from Bacillus subtilis has been purified to near homogeneity (Kuhn \& Ward, 1998). It appears to differ from other $\mathrm{PP}_{\mathrm{i}}$ ases in its absolute requirement for activation by 
$\mathrm{Mn}^{2+}$ or $\mathrm{Co}^{2+}$ ions. It also differs from most other prokaryotic $\mathrm{PP}_{\mathrm{i}}$ ases in having a subunit molecular mass of $34000 \mathrm{Da}$.

In this paper we report the identity of the B. subtilis $\mathrm{PP}_{i}$ ase with the translation product of an ORF $(y y b Q)$ of hitherto unknown function in the B. subtilis genome. From its sequence, the $\mathrm{PP}_{\mathrm{i}}$ ase appears unrelated to other sequenced $\mathrm{PP}_{\mathrm{i}}$ ases, but shows significant similarity to three other putative prokaryotic proteins of unknown function and possibly to an exopolyphosphatase (metaphosphatase) from yeast. We discuss the possibility of a new class of $\mathrm{PP}_{\mathrm{i}}$ ase enzyme, designated type $\mathrm{C}$ to distinguish it from previously characterized enzymes of prokaryotes and eukaryotes, designated types $\mathrm{A}$ and $\mathrm{B}$, respectively. We have cloned the $y y b Q$ gene in $E$. coli and have overexpressed the protein. The latter is produced within the cytosol, and appears identical in size and properties to the $\mathrm{PP}_{\mathrm{i}}$ ase isolated directly from $B$. subtilis WB600.

\section{METHODS}

Analysis of $\mathrm{N}$-terminal sequence. $B$. subtilis $\mathrm{WB} 600 \mathrm{PP}_{\mathrm{i}}$ ase was purified as described by Kuhn \& Ward (1998). The preparation was subjected to SDS-PAGE and proteins were transferred to a PVDF membrane by electroblotting using a Pharmacia semi-dry blotting apparatus. Electrophoretic transfer proceeded at $2.5 \mathrm{~mA}(\mathrm{~cm} \mathrm{gel})^{-2}$ for $30 \mathrm{~min}$. The PVDF membrane was stained with Coomassie blue R250, destained and dried. Stained bands were cut out from the membrane and the protein was sequenced by Edman degradation using an applied Biosystems 473A automatic sequencer (Alta Bioscience, University of Birmingham).

Informatics. The B. subtilis genome database at http:// www/pasteur.fr/cgi-bin/subti/SubtiList was searched with the N-terminal sequence of the protein. Subsequently, comparison and analysis of the putative ORF yybQ gene product was made using the GCG package (version 9.1, Genetics Computer Group, Madison, WI, USA); Clustal w at Seqnet, Daresbury (Thompson et al., 1994) and internet links to BLAST, Motifs and Blocks via the World Wide Web site of the Molecular Biology User Group, University of Birmingham.

Isolation of B. subtilis DNA. B. subtilis WB600, obtained from $\mathrm{S}$. Wong, University of Calgary, Alberta, Canada, was grown in shaken culture at $37^{\circ} \mathrm{C}$ in LB broth. The cells from duplicate $5 \mathrm{ml}$ overnight cultures were separately centrifuged (MSE Microcentaur; 13000 r.p.m.) and washed by suspension and recentrifugation in $5 \mathrm{ml}$ sterile distilled water. The pellets were drained and the DNA extracted from each using an IGI Gene DNA Extraction kit (Immunogen International) according to the manufacturer's protocol.

PCR and cloning. Primers for PCR were made by Alta Bioscience. For PCR reactions, the final concentration of each dNTP was $20 \mu \mathrm{M}$ and that of each primer $4 \mu \mathrm{M}$. Vent $_{\mathrm{R}}$ DNA polymerase (New England Biolabs) was used according to the manufacturer's instructions in a final volume of $50 \mu \mathrm{l}$. In PCR, the annealing and extension temperatures were $59^{\circ} \mathrm{C}$ and $72{ }^{\circ} \mathrm{C}$, respectively and 25 cycles were used. PCR product was purified using a QiaexII agarose extraction kit (Qiagen) according to the manufacturer's protocol. The purified PCR product was ligated into vector pET11c (Novogen), cur with BamHI and NdeI and treated with shrimp alkaline phosphatase. Ligation was overnight at room temperature with 1 unit T4 DNA ligase. For transformation, $100 \mu \mathrm{l}$ competent $E$. coli DH5 $\alpha$ cells (Sambrook et al., 1989) were mixed with $5 \mu \mathrm{l}$ ligation mixture and plated onto LB agar plates containing $100 \mu \mathrm{g}$ ampicillin $\mathrm{ml}^{-1}$. Plasmid DNA was extracted from the cultures using the miniprep procedure described by Sambrook et al. (1989), and was screened for the presence of insert by PCR using primers supplied by Novogen.

Overexpression. Plasmid DNA was extracted from two different clones of transformed $\mathrm{DH} 5 \alpha$ cells and used to transform the overexpression strain E. coli BL21 (DE3). The procedure described by Novogen, with $100 \mu \mathrm{g}$ ampicillin $\mathrm{ml}^{-1}$ in all media and $1 \mathrm{mM}$ IPTG as inducer, was used to overexpress the protein. Samples $(100 \mu \mathrm{l})$ were withdrawn from cultures, mixed with an equal volume of $2 \times$ sample buffer (Laemmli, 1970), heated at $90^{\circ} \mathrm{C}$ for $5 \mathrm{~min}$, then analysed by SDS-PAGE $[10 \%(\mathrm{w} / \mathrm{v})$ acrylamide gel] using a Hoeffer Mighty Small II apparatus.

Cultures $(200 \mathrm{ml})$ of induced cells were harvested by centrifugation $(2000 \mathrm{~g}, 15 \mathrm{~min})$, washed by suspension and recentrifugation in $1.15 \mathrm{M} \mathrm{KCl}, 10 \mathrm{mM}$ MOPS, $\mathrm{pH} 7.0$ (extraction buffer) and resuspended in $20 \mathrm{ml}$ of the same buffer. This suspension was sonicated for $4 \times 30 \mathrm{~s}$ with $1 \mathrm{~min}$ on ice between each period of sonication. The sonicated extract was centrifuged at $12000 \mathrm{~g}$ for $15 \mathrm{~min}$ at $4{ }^{\circ} \mathrm{C}$. The supernatant was retained, dispensed in $1 \mathrm{ml}$ aliquots and stored at $-20^{\circ} \mathrm{C}$.

Characteristics of the overexpressed protein. Samples were analysed by SDS-PAGE and by matrix-assisted laser desorption and ionization mass spectrometry (MALDI-MS) using a Kratos Kompact analytical mass spectrometer. Samples were also assayed for protein content (Bradford, 1976). $\mathrm{PP}_{\mathrm{i}}$ ase activity, and effects of different metal ions on both activation and activity, were tested in duplicate as described by Kuhn \& Ward (1998). Equivalent samples obtained from induced control cultures of E. coli BL21 (DE3) containing pET11c without insert were also analysed.

\section{RESULTS AND DISCUSSION}

\section{B. subtilis $\mathrm{PP}_{\mathrm{i}}$ ase is the product of gene yybQ}

The $\mathrm{N}$-terminal sequence of the first 15 amino acids of the major protein species in the purified $\mathrm{PP}_{\mathrm{i}}$ ase was MEKILIFGHQNPDTD. This sequence was used to probe the $B$. subtilis genome database and showed complete identity with the first 15 amino acids of the protein encoded by $B$. subtilis yybQ (SP:P37487), an ORF with no previously assigned function (Ogasawara et al., 1994; Kunst et al., 1997). The translated product of $y y b Q$ comprises 309 amino acids and has a calculated molecular mass of $33988.5 \mathrm{Da}$. This value agrees well with that of $34019 \mathrm{Da}$ obtained by MALDI-MS for the major component of the purified enzyme (Kuhn \& Ward, 1998). However it remained essential to clone and overexpress this gene and show that the product was identical to the $B$. subtilis $\mathrm{PP}_{\mathrm{i}}$ ase in size and in enzymic characteristics. It was also important to show that overexpressed enzyme differed from the native $\mathrm{PP}_{\mathrm{i}}$ ase of the host strain used (E. coli).

\section{Cloning and overexpression of yybQ}

The full-length coding region of $y y b Q$ was amplified from genomic DNA of $B$. subtilis WB600 with the oligonucleotide primers (a) 5' GGAATTCCATATGGAAAAGATACTTATTTTCGGGAC $3^{\prime}$ and (b) 5' GG- 


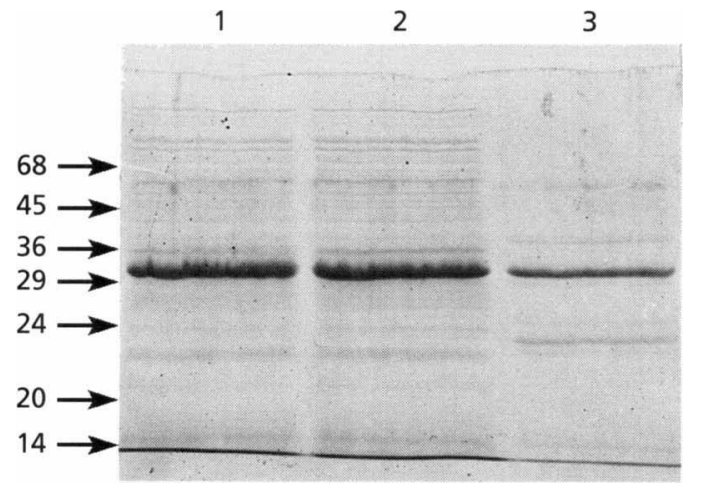

Fig. 1. SDS-PAGE ( $10 \%$ acrylamide) of $B$. subtilis PP ase. Lanes and 2, samples from E. coli BL21 (DE3) in which the enzyme was overexpressed. Lane 3, sample of enzyme purified from $B$. subtilis. Molecular mass values are shown at the left of the figure in $\mathrm{kDa}$.

AAGCTTGGATCCTTATTCAGCCATTGCGTATGTTAC 3'. These introduced EcoRI and NdeI restriction endonuclease sites at the $5^{\prime}$ end, and HindIII and $B a m H I$ sites at the $3^{\prime}$ end of the amplified fragment, respectively. In each of two parallel amplifications a single product of approximately $1 \mathrm{~kb}$ was obtained. Each product was cloned in-frame into $E$. coli expression vector pET11c using the unique NdeI and BamHI sites and transformed first into $E$. coli strain DH5 $\alpha$ (for maintenance and storage) and then further into strain BL21 (DE3). After suitable growth of transformed BL21 (DE3), overexpression of $\mathrm{PP}_{i}$ ase was induced by addition of IPTG. PP ${ }_{i}$ ase activity was located only in the cytosolic fraction of the cells, and was maximally induced $2-3 \mathrm{~h}$ after addition of IPTG. Analysis of soluble extracts by SDS-PAGE revealed, for each of the two parallel experiments, a single major band against a background of minor bands of $E$. coli endogenous proteins. The major band migrated identically to the $\mathrm{PP}_{\mathrm{i}}$ ase purified from B. subtilis (Fig. 1) and was electrophoretically transferred onto PVDF membrane. Sequencing of this material showed identity of the first 15 amino acids to those of the purified $B$. subtilis $\mathrm{PP}_{\mathrm{i}}$ ase (see above). Analysis of whole-cell extracts by MALDI-MS gave a single major peak of molecular mass 34011 and 34029 for the two separately isolated clones. These values are, within experimental error, indistinguishable from each other and from that of the purified B. subtilis enzyme (Kuhn \& Ward, 1998). In contrast, the native E. coli $\mathrm{PP}_{\mathrm{i}}$ ase has a deduced molecular mass of 19572 (Lahti et al., 1988).

\section{Enzymic characteristics of overexpressed PPase}

The $\mathrm{PP}_{\mathrm{i}}$ ase activity of clarified cell extracts of E. coli with and without overexpression were compared. The absolute activities differed profoundly, being about $10 \mu \mathrm{mol} \mathrm{PP}$ hydrolysed $\min ^{-1}$ ( $\mathrm{mg}$ protein $)^{-1}$ for the native E. coli enzyme and about $6000 \mu \mathrm{mol} \mathrm{PP}_{\mathrm{i}}$ hydrolysed $\min ^{-1}$ (mg protein $)^{-1}$ for the overexpressed enzyme. Remarkably, this latter specific activity somewhat exceeded the highest specific activity obtained with $\mathrm{PP}_{\mathrm{i}}$ ase purified to near homogeneity from $B$. subtilis (Kuhn \& Ward, 1998). The tested properties of the overexpressed protein accorded with those of the native $B$. subtilis enzyme, but not with those of the native $E$. coli enzyme. Thus, at $\mathrm{pH} 7$ the E. coli enzyme hydrolysed Mg.PP ${ }_{i}$ and $\mathrm{Zn} \cdot \mathrm{PP}_{\mathrm{i}}$ substrates at equal rates, using each metal ion at optimal concentration. In contrast, the overexpressed enzyme, and the native $B$. subtilis enzyme, hydrolysed $\mathrm{Zn} . \mathrm{PP}_{\mathrm{i}}$ only about $17 \%$ as fast as $\mathrm{Mg} \mathrm{PP}_{\mathrm{i}}$ (Table 1).

Exposure of the native E. coli enzyme to $1 \mathrm{mM}$ EDTA for $12 \mathrm{~min}$ did not impair its catalytic activity when subsequently presented with $\mathrm{Mg}$.PP ${ }_{i}$ substrate (Fig. 2a). Similar activities were evoked when the enzyme was pretreated first with EDTA and then with either $\mathrm{Ni}^{2+}$, $\mathrm{Cd}^{2+}, \mathrm{Zn}^{2+}, \mathrm{Sn}^{2+}, \mathrm{Cu}^{2+}, \mathrm{Ca}^{2+}, \mathrm{Mg}^{2+}, \mathrm{Sr}^{2+}$ or $\mathrm{Ba}^{2+}$ (Fig. 2a), giving a metal ion concentration $1.4 \mathrm{mM}$ over and above the prevailing concentration of EDTA. Prior exposure to $\mathrm{Mn}^{2+}$ or $\mathrm{Co}^{2+}$ did, however, yield increased

\section{Table 1. $\mathrm{PP}_{\mathrm{i}}$ ase activity in bacterial extracts}

Cultures of E. coli BL21 (DE3) were grown in LB broth with ampicillin and induced with IPTG. $B$. subtilis WB600 was grown as described by Kuhn \& Ward (1998). Cells were broken by sonication and the extracts clarified by centrifugation. The total $\mathrm{PP}_{\mathrm{i}}$ ase activity of extracts was adjusted to similar levels and determined as described by Kuhn \& Ward (1998) in the presence or absence of Zn.PP ${ }_{i}$ or Mg.PP ${ }_{i}$ substrates.

\begin{tabular}{|c|c|c|c|c|}
\hline \multirow[t]{2}{*}{$\begin{array}{l}\text { Source of } \mathrm{PP}_{\mathrm{i}} \text { ase } \\
\text { activity }\end{array}$} & \multicolumn{3}{|c|}{$\begin{array}{c}\text { Catalytic activity } \\
{\left[\mu \mathrm{mol} \mathrm{P}_{\mathrm{i}} \text { formed }(2 \mathrm{~min})^{-1}\right]}\end{array}$} & \multirow[t]{2}{*}{$\begin{array}{l}\text { Inhibition by } \\
\text { fluoride }(\%)\end{array}$} \\
\hline & $\mathbf{P P}_{\mathrm{i}}$ & $M g . P P_{i}$ & $\mathrm{Zn}_{\mathrm{PP}} \mathrm{i}_{\mathrm{i}}$ & \\
\hline E. coli BL21 (DE3) & 0.004 & $0 \cdot 236$ & $0 \cdot 240$ & 86 \\
\hline B. subtilis WB600 & 0.004 & $0 \cdot 278$ & $0 \cdot 044$ & 11 \\
\hline $\begin{array}{l}\text { E. coli BL21 (DE3) } \\
\text { overexpressing B. subtilis } \\
\mathrm{PP}_{\mathrm{i}} \text { ase }\end{array}$ & $0 \cdot 008$ & $0 \cdot 240$ & $0 \cdot 038$ & 0 \\
\hline
\end{tabular}




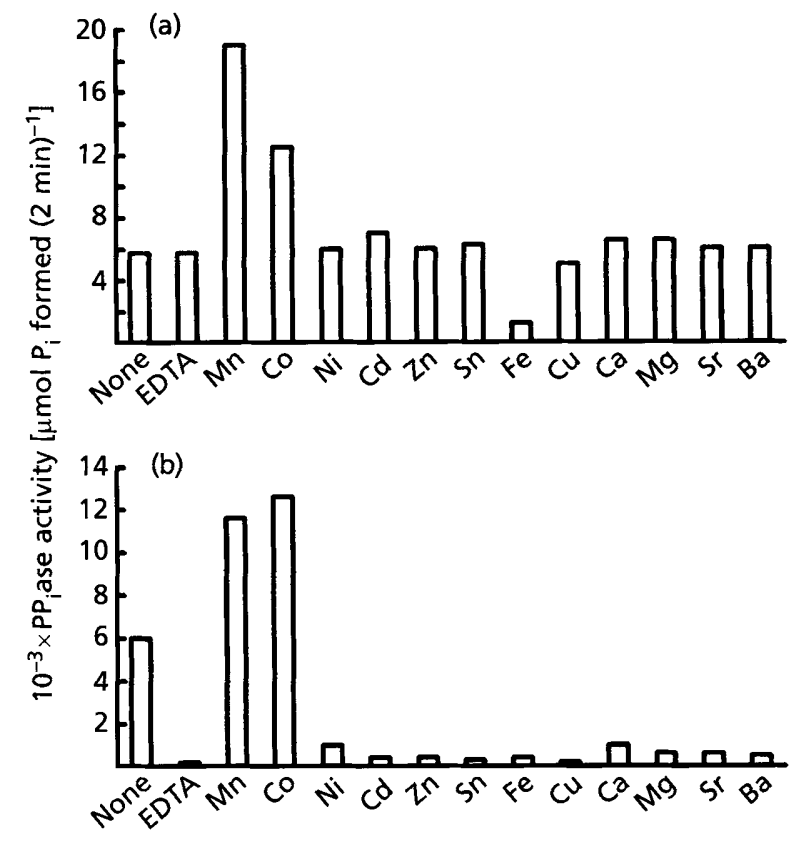

Fig. 2. Effect of pretreating $P_{i}$ ase with EDTA, or with EDTA followed by metal ion, prior to assay with $M g . P P_{i}$. (a) Native $E$. coli $\mathrm{PP}_{\mathrm{i}}$ ase, (b) $E$. coli extract containing overexpressed $B$. subtilis $\mathrm{PP}_{\mathrm{i}}$ ase. The enzyme was mixed with an equal volume of $2 \mathrm{mM}$ EDTA in $25 \mathrm{mM}$ BES buffer $\mathrm{pH} 7$ containing $0.04 \mathrm{mg}$ bovine serum albumin $\mathrm{ml}^{-1}$ and incubated for $12 \mathrm{~min}$ at $37^{\circ} \mathrm{C}$. It was then either diluted appropriately and assayed, or else diluted fivefold into $2 \mathrm{mM}$ metal salt in the same BES/serum albumin buffer and incubated a further $45 \mathrm{~min}$ at $25^{\circ} \mathrm{C}$. For enzyme assay, $10-50 \mathrm{ml}$ samples were mixed with $0.45 \mathrm{ml}$ of a solution containing $25 \mathrm{mM}$ DL-serine, $1 \mathrm{mM} \mathrm{Na.PP}, 1 \mathrm{mM}$ EDTA and $5 \mathrm{mM} \mathrm{MgCl}_{2}$ at $\mathrm{pH} 9.0$ (Kuhn \& Ward, 1998). Transition metal ions were effectively removed by complexing with EDTA in the assay.

subsequent activity (Fig. 2a). The effect of these two metal ions appears not to have been previously reported. By contrast, the overexpressed $\mathrm{PP}_{\mathrm{i}}$ ase lost all $\mathrm{Mg} \cdot \mathrm{PP}_{\mathrm{i}}$ hydrolytic activity after exposure to EDTA. This was restored by further prior exposure to $\mathrm{Mn}^{2+}$ or $\mathrm{Co}^{2+}$, but not by exposure to the other ions listed above (Fig. 2b). The overexpressed enzyme could undergo two complete cycles of activation and deactivation by sequential treatment with alternating excesses of $\mathrm{Mn}^{2+}$ and EDTA prior to presentation of the Mg.PP $\mathrm{P}_{\mathrm{i}}$ substrate (Fig. 3). This complete dependence on prior activation by $\mathrm{Mn}^{2+}$ (or $\mathrm{Co}^{2+}$ ) is characteristic of the purified B. subtilis enzyme (Kuhn \& Ward, 1998).

\section{Sequence similarities of $B$. subtilis $\mathrm{PP}_{\mathrm{i}}$ ase with other proteins}

Computer analysis of the protein database showed no similarity of $B$. subtilis $\mathrm{PP}_{\mathrm{i}}$ ase to other $\mathrm{PP}_{\mathrm{i}}$ ases even though they show significant similarities among themselves (Cooperman et al., 1992; Teplyakov et al., 1994). However, the local alignment search programme BLAST detected very highly significant $\left(P<2.2 \times 10^{-56}\right)$

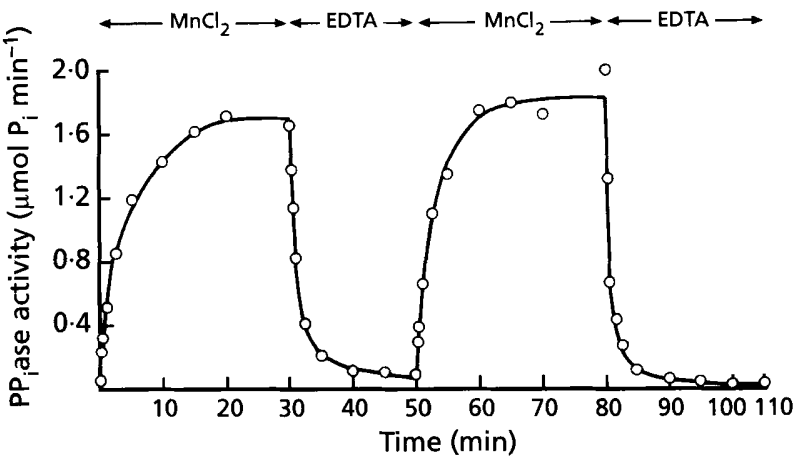

Fig. 3. Cyclic activation and deactivation of $\mathrm{PP}_{\mathrm{i}}$ ase by addition and withdrawal of $\mathrm{Mn}^{2+}$ ions. Overexpressed PP ase deactivated with I mM EDTA was diluted to $2.5 \mathrm{ml}$ at $25^{\circ} \mathrm{C}$ with $25 \mathrm{mM}$ MES buffer $\mathrm{pH} 7.0$ containing $0.04 \mathrm{mg}$ bovine serum albumin $\mathrm{ml}^{-1}$. At the times shown, successive additions were then made of $0.1 \mathrm{M} \mathrm{MnCl}_{2}(10 \mu \mathrm{l}), 0.15 \mathrm{M}$ EDTA $(9.6 \mu \mathrm{l}), 0.15 \mathrm{M} \mathrm{MnCl}_{2}(9.2 \mu \mathrm{l})$ and $0.15 \mathrm{M}$ EDTA $(8.8 \mu \mathrm{l})$. Samples $(10 \mu \mathrm{l})$ were taken, as shown, for PP ase assay (Kuhn \& Ward, 1998).

similarities between $B$. subtilis $\mathrm{PP}_{\mathrm{i}}$ ase and three predicted proteins of unknown function, namely ORF mj0608 of the archaeon Methanococcus jannaschi (gi:1591318; Bult et al., 1996), ORF1 of pCW1 from Streptococcus gordonii DL1 (gi:1743856; Whittaker et al., 1996) and AF0756 of the archaeon Archaeoglobus fulgidus (AE000782; Klenk et al., 1997). Simple pairwise analyses of the sequences, using the program GAP, showed more than $40 \%$ sequence identity and more than $50 \%$ sequence similarity. Fig. 4 shows the alignment of the four proteins made by the program CLUSTAL w. Identical and conservatively replaced residues are seen to be distributed throughout the proteins, including two runs of approximately 10 residues, each near the $\mathrm{N}$ and C-terminal ends, respectively. There is also clear homology with the $16 \mathrm{~N}$-terminal residues of a $34000 \mathrm{Da}$ protein from Bacillus megaterium. This protein is almost certainly be identical to the $\mathrm{Mn}^{2+}$-activated $\mathrm{PP}_{\mathrm{i}}$ ase of this organism (unpublished observations). The four proteins, or predicted proteins, shown in Fig. 4 are similar in their sizes $(309,307,311$ and 322 amino acids respectively), in their calculated isoelectric points (4.53, $4.83,4.34$ and 4.77 , respectively) and in the apparent conservation of four histidines. Other potentially active conserved groups include serine, arginine and lysine, but not cysteine. Therefore it can be predicted with some confidence that the M. jannaschii, S. gordonii and $A$. fulgidus gene sequences also encode $\mathrm{PP}_{\mathrm{i}}$ ases. The $\mathrm{PP}_{\mathrm{i}}$ ases of other organisms (Cooperman et al., 1992; Teplyakov et al., 1994) including Bacillus stearothermophilus and one representative of the Archaea, Sulfolobus acidocaldarius (Meyer et al., 1995), show convincing similarities among themselves and to class A enzymes but not to the protein sequences discussed in this paper. Their similarities are confined to about 24 residues, 17 of them associated with the active site. In the most completely studied $\mathrm{PP}_{\mathrm{i}}$ ases of Saccharomyces cerevisiae and E. coli, chemical modification and site-directed 


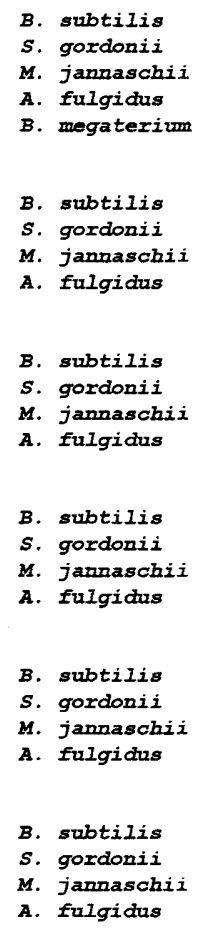

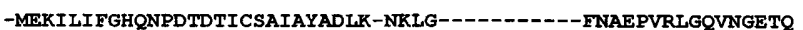
-MSKILVFGHONPDSDAIGSSYAFAY LAREAYG-------DDTEAVALGEPNEETA

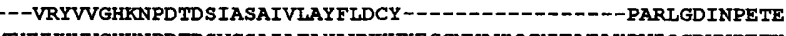
MEHVVYVVGHKNPDTDSVCSAIAFAYLWNKWKEGGNVAKMMKIEAEAKPVIQGDVNPETK QKTLIFGHKNPDTDTI

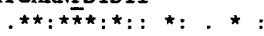

YALDY FKQES PRLVETAANE-VNGVI LVDHNERQQS IKDIEEVQVLEVIDHHRIANFETA FVLDYFGVAAPRVITSAKAEGAEQVILTDHNEFQQSVADIAEVEVYGVVDHHRVANFETA FVIRKFGVME PELIESAKGK---EIILVDHSEKSOSFDDLEEGKLIAI IDHHKVG-LTTT YVLEKFGFEVPEIMTNGEGK---KVALVDHSEKAQTVDGIDKAEVVAIVDHHKIGDVTTP

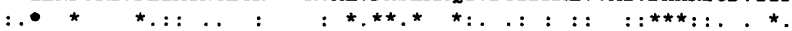

EPLYYRAEPVGCTATILNKMYKENNVKIE---------KEIAGLMLSAI I SDSLLFKSPTC NPLYMRLEPVGSASSIVYRMFKEHSVAVS--------KEIAGLMLSGLISDTLLLKSPTT PILYYAKPVGSTATVIAELYFKDAIDLIGGKKKELKPDLAGLLLSAII SDTVIFRSPTVT QPILFVNLPVGCTATVIKLLFDKTGVEIP--.-----KDIAGILISSILSDTVIFKSATT

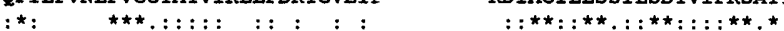

TDQDVAAAKELAEIAGVD-AEEYGLMMLKAGADLSKKTVEELISLDAKEFTLGSKKVEIA HPTDKAIAPELAELAGVN - LEEYGLAMLKAGTNLASKSAEELIDIDAKTFELNGNNVRVA TDLDKEMAKRIAE IAGI SNIEETGMEI I KARSVVGKLKPEEI INMD EKNED FNGKKVGIG

QVNTVDIEDVKKRQAELEAVI SKVVAEKNLDLFLLVITDILENDSLALAIGNEAAKVEKA QVNTVDIAEVLERQAEI FAAIFKAIADNGY SDFVLMI TDI INSNSEILAIGSNMDKVEAA QVEVIDVSEVESKKEDIYKLLEEKLKNEGYDLIVELI TDIMKEGSEALVVGNK-EMFEKA QIELVDLSLIESRIDEIYEAMKKMKEEGGYAGIFIMLTDIMKEGTELLVVTDYPEVVEKA

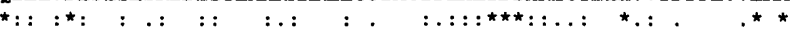

FNVTLLENNTALLKGVVSRKKOVVPVLTDAMAETNFVLENNHAFLAGAVSRKKOVVPOLTES FNAFNVKVEGNSVFLEGVMSRKKOVVPPLERAYNGTGKKLEGKSVWLDGVMSRKROVVPPLEKAFAEI

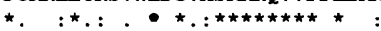

Fig. 4. Multiple sequence alignment using CLUSTAL W (version 1.74) of proteins showing highly significant similarity to the $\mathrm{PP}_{\mathrm{i}}$ ase from $B$. subtilis. Asterisks denote fully conserved residues. Colons indicate that one of the following 'strong' groups is fully conserved: STA, NEQK, NHQK, NDEQ, QHRK, MILV, MILF, HY, FYW. Full stops indicate that one of the following 'weaker' groups is fully conserved: CSA, ATV, SAG, STNK, STPA, SGND, SNDEQK, NDEQHK, NEQHRK, FVLIM, HFY. Sequence information from the $N$ terminus of $\mathrm{PP}_{\mathrm{j}}$ ase from $B$. megaterium (unpublished data) is also included. The underlined residues $Q$ and $P$ have not been unequivocally identified. mutagenesis have been used to identify active site residues (reviewed by Cooperman et al., 1992). These enzymes show a conserved tyrosine and arginine at the putative active site. In contrast, no tyrosine is conserved in the four proteins shown in Fig. 4. Another contrasting feature of previously studied $\mathrm{PP}_{\mathrm{i}}$ ases is the lack of conservation of histidine residues. These differences indicate that class $\mathrm{C}$ enzymes have a structurally distinct active site from enzymes of class $\mathrm{A}$ and $\mathrm{B}$.

The global alignment programme FASTA gave low scores for two further proteins, an exopolyphosphatase (metaphosphatase) from S. cerevisiae (Wurst et al., 1995) and an ORF of unknown function from B. subtilis. Even though not statistically significant, given the functional similarity of exopolyphosphatase and $\mathrm{PP}_{\mathrm{i}}$ ase there may be biological significance in this association. However, the $S$. cerevisiae enzyme does not hydrolyse $\mathrm{PP}_{\mathrm{i}}$, whereas the $B$. subtilis $\mathrm{PP}_{\mathrm{i}}$ ase, in contrast to exopolyphosphatase, does not hydrolyse tetraphosphate (Kuhn \& Ward, 1998). Consequently, if the two proteins are related their roles have now diverged. Pair-wise analysis using GAP gave low scores for identical and similar residues. Although inorganic $\mathrm{PP}_{\mathrm{i}}$ ase activity is normally assumed to be essential, for example for efficient DNA replication and transcription and for amino acid activation, the complete genomic sequences of M. jannaschii, B. subtilis and A. fulgidus do not contain any sequences representative of the hitherto recognized group of $\mathrm{PP}_{\mathrm{i}}$ ases. Interestingly, the genome of Borrelia burgdorferi appears to encode no recognized $\mathrm{PP}_{\mathrm{i}}$ ase. It may be that its $\mathrm{PP}_{\mathrm{i}}$ is disposed of by its unusual $\mathrm{PP}_{\mathrm{i}}$-driven phosphofructokinase (Fraser et al., 1997).

\section{A proposed new classification of $\mathrm{PP}_{\mathrm{i}}$ ases}

The unusual $\mathrm{Mn}^{2+}$-dependence of the $\mathrm{PP}_{\mathrm{i}}$ ase from $B$. subtilis, together with its apparently novel amino acid sequence, suggest that it may represent a new class of $\mathrm{PP}_{\mathrm{i}}$ ase. To assess this possibility we have compared the known properties of some 38 actual or putative $\mathrm{PP}_{\mathrm{i}}$ ases hitherto reported (Table 2 ). The data are naturally incomplete, and certain items bear some qualification. Nevertheless, alone on the basis of molecular mass (or number of amino acid residues) and prokaryotic/ eukaryotic difference, the enzymes appear to fall quite readily into three classes.

Class $\mathrm{A}$ is characterized by prokaryotic $\mathrm{PP}_{\mathrm{i}}$ ases of subunit size 164-184 amino acids and of molecular mass approximately $20 \mathrm{kDa}$. They are typically tetramers or hexamers, and have specific activities of roughly $1000 \mu \mathrm{mol} \mathrm{min}^{-1}$ (mg protein $)^{-1}$. The exceptionally low reported specific activity of $\mathrm{PP}_{\mathrm{i}}$ ase from Bartonella bacilliformis may bear re-examination. Puzzling is the report of an apparently class-A-type $\mathrm{PP}_{\mathrm{i}}$ ase from $B$. subtilis (Shimizu et al., 1997), since the genome of this organism lacks the expected homologous sequence. Significant similarity $\left(3 \mathrm{e}^{-20}\right)$ is also found between the $E$. coli $\mathrm{PP}_{\mathrm{i}}$ ase and contig 204 of the Neisseria gonorrboeae sequence accessed via http://dna1.chem.uoknor.edu.

Class $\mathrm{B} \mathrm{PP} \mathrm{P}_{\mathrm{i}}$ ases are all eukaryotic and are mostly larger, with subunits of about 285 amino acids and molecular mass around $32 \mathrm{kDa}$. These $\mathrm{PP}_{\mathrm{i}}$ ases are generally dimers, although the mitochondrial members are heterodimers that generate $\alpha_{2} \beta_{2}$ tetramers on association with the membrane. Although the $\mathrm{PP}_{\mathrm{i}}$ ases of $S$. cerevisiae, 
Table 2. Classification and key properties of $\mathrm{PP}_{\mathrm{i}}$ ase

\begin{tabular}{|c|c|c|c|c|c|c|c|c|c|}
\hline \multirow{2}{*}{$\begin{array}{l}\text { Ref. } \\
\text { no.* }\end{array}$} & \multirow{2}{*}{$\begin{array}{l}\text { Proposed enzyme } \\
\text { class and example }\end{array}$} & \multicolumn{2}{|c|}{ Molecular mass (kDa) } & \multirow{2}{*}{$\begin{array}{l}\text { No. of } \\
\text { amino } \\
\text { acids }\end{array}$} & \multirow{2}{*}{$\begin{array}{l}\text { No. of } \\
\text { subunits }\end{array}$} & \multirow{2}{*}{$\begin{array}{l}\text { Highest } \\
\text { specific } \\
\text { activity } †\end{array}$} & \multirow{2}{*}{$\begin{array}{l}\text { Activity } \\
\text { shown? }\end{array}$} & \multirow{2}{*}{$\begin{array}{l}\text { Fluoride } \\
\text { sensitivity }\end{array}$} & \multirow{2}{*}{$\begin{array}{l}\text { SH poison } \\
\text { sensitivity }\end{array}$} \\
\hline & & Experimental & Deduced & & & & & & \\
\hline 1 & $\begin{array}{l}\text { Class A PP ases } \\
\text { Bacillus } \\
\text { stearothermophilus/PS3 }\end{array}$ & 18 & 19 & 164 & 6 & 1110 & Yes & Yes & Yes \\
\hline 2 & Bacillus subtilis & 24 & NA & NA & 4 or 6 & 875 & Yes & NA & $\mathrm{NA}$ \\
\hline 3 & Bartonella bacilliformis & $22-23$ & 20 & 177 & NA & 26 & Yes & NA & NA \\
\hline 4 & Escherichia coli & 18 & 20 & 175 & 6 & 1333 & Yes & Yes & No \\
\hline 5 & Haemophilus influenzae & $\mathrm{NA}$ & 20 & 176 & NA & NA & No & NA & NA \\
\hline 6 & Helicobacter pylori & NA & 19 & 173 & NA & NA & No & $\mathrm{NA}$ & NA \\
\hline 7 & $\begin{array}{l}\text { Methanobacterium } \\
\text { thermoautotrophicum }\end{array}$ & 25 & NA & $\mathrm{NA}$ & NA & 1233 & Yes & Yes & $\mathrm{NA}$ \\
\hline 8 & Mycoplasma genitalium & NA & 22 & 184 & NA & NA & No & NA & NA \\
\hline 9 & Mycoplasma pneumoniae & $\mathrm{NA}$ & 21 & 184 & $\mathrm{NA}$ & $\mathrm{NA}$ & No & NA & NA \\
\hline 10 & Sulfolobus acidocaldarius & 17 & 19 & 173 & 4 & 672 & Yes & NA & NA \\
\hline 11 & Thermoplasma acidophilum & 22 & 21 & 179 & 6 & 1500 & Yes & NA & NA \\
\hline 12 & Thermus thermophilus & 19 & NA & 176 & 6 & 250 & Yes & NA & NA \\
\hline 13 & Thiobacillus thiooxidans & 20 & NA & NA & 4 & 402 & Yes & Yes & Yes \\
\hline & Class B PP ases & & & & & & & & \\
\hline 14 & Arabidopsis thaliana & NA & 30 & 263 & NA & NA & No & NA & NA \\
\hline 15 & $\begin{array}{l}\text { Bovine heart } \\
\text { mitochondria I }\end{array}$ & 28,30 & NA & NA & 2 & 250 & Yes & Yes & NA \\
\hline 16 & Bovine liver & NA & NA & NA & NA & NA & Yes & Yes & Yes \\
\hline 17 & Bovine retina & 36 & 32 & 289 & 2 & 885 & Yes & Yes & Yes \\
\hline 18 & Chicken liver & 49 & NA & NA & 2 & 120 & Yes & Yes & NA \\
\hline 19 & Human erythrocyte & 20 & $\mathrm{NA}$ & NA & NA & 80 & Yes & $\mathrm{NA}$ & Yes \\
\hline 20 & Kluyveromyces lactis & NA & 32 & 286 & $\mathrm{NA}$ & $\mathrm{NA}$ & No & NA & $\mathrm{NA}$ \\
\hline 21 & Pig brain & 33 & NA & NA & 2 & 993 & Yes & Yes & NA \\
\hline 22 & Pig cartilage & $\mathrm{NA}$ & NA & NA & NA & 397 & Yes & Yes & (Yes) \\
\hline 23 & Potato & NA & 24 & $\mathrm{NA}$ & NA & NA & No & NA & NA \\
\hline 24 & $\begin{array}{l}\text { Rabbit skeletal } \\
\text { muscle }\end{array}$ & 35 & NA & NA & 2 & 340 & Yes & NA & Yes \\
\hline 25 & $\begin{array}{l}\text { Rat heart } \\
\text { mitochondria I }\end{array}$ & 30 & $\mathrm{NA}$ & $\mathrm{NA}$ & 2 & $\mathrm{NA}$ & Yes & $\mathrm{NA}$ & $\mathrm{NA}$ \\
\hline 26 & $\begin{array}{l}\text { Rat heart } \\
\text { mitochondria II }\end{array}$ & 28,30 & $\mathrm{NA}$ & $\mathrm{NA}$ & 4 & 92 & Yes & $\mathrm{NA}$ & NA \\
\hline 27 & Rat liver cytosol & $30-34$ & NA & $\mathrm{NA}$ & 2 & 360 & Yes & Yes & NA \\
\hline 28 & $\begin{array}{l}\text { Rat liver } \\
\text { mitochondria I }\end{array}$ & 34 & NA & NA & 2 & $\mathrm{NA}$ & Yes & Yes & $\mathrm{NA}$ \\
\hline 28 & $\begin{array}{l}\text { Rat liver } \\
\text { mitochondria II }\end{array}$ & 28,35 & NA & $\mathrm{NA}$ & 4 & 92 & Yes & Yes & $\mathrm{NA}$ \\
\hline 29 & $\begin{array}{l}\text { Saccharomyces } \\
\text { cerevisiae I }\end{array}$ & $\mathrm{NA}$ & 32 & 286 & 2 & 750 & Yes & Yes & $(\mathrm{No})$ \\
\hline 30 & $\begin{array}{l}\text { Saccharomyces } \\
\text { cerevisiae II }\end{array}$ & NA & 32 & 280 & NA & $\mathrm{NA}$ & No & $\mathrm{NA}$ & NA \\
\hline 31 & $\begin{array}{l}\text { Schizosaccharomyces } \\
\text { pombe }\end{array}$ & $\mathrm{NA}$ & $32 \cdot 5$ & 289 & $\mathrm{NA}$ & $\mathrm{NA}$ & No & $\mathrm{NA}$ & NA \\
\hline
\end{tabular}

Table continued on facing page 
Table 2 (cont)

\begin{tabular}{|c|c|c|c|c|c|c|c|c|c|}
\hline \multirow{2}{*}{$\begin{array}{l}\text { Ref. } \\
\text { no.* }\end{array}$} & \multirow{2}{*}{$\begin{array}{l}\text { Proposed enzyme } \\
\text { class and example }\end{array}$} & \multicolumn{2}{|c|}{ Molecular mass $(\mathrm{kDa})$} & \multirow{2}{*}{$\begin{array}{l}\text { No. of } \\
\text { amino } \\
\text { acids }\end{array}$} & \multirow{2}{*}{$\begin{array}{l}\text { No. of } \\
\text { subunits }\end{array}$} & \multirow{2}{*}{$\begin{array}{l}\text { Highest } \\
\text { specific } \\
\text { activity } †\end{array}$} & \multirow{2}{*}{$\begin{array}{l}\text { Activity } \\
\text { shown? }\end{array}$} & \multirow{2}{*}{$\begin{array}{l}\text { Fluoride } \\
\text { sensitivity }\end{array}$} & \multirow{2}{*}{$\begin{array}{l}\text { SH poison } \\
\text { sensitivity }\end{array}$} \\
\hline & & Experimental & Deduced & & & & & & \\
\hline 32 & $\begin{array}{l}\text { Class C PP }{ }_{i} \text { ases } \\
\text { Archaeoglobus } \\
\text { fulgidus }\end{array}$ & NA & 35 & 322 & NA & NA & No & NA & NA \\
\hline 33 & $\begin{array}{l}\text { Bacillus } \\
\text { megaterium }\end{array}$ & 34 & NA & $\mathrm{NA}$ & NA & NA & Yes & No & $\mathrm{NA}$ \\
\hline 34 & Bacillus subtilis & 34 & 34 & 309 & 2 or 3 & 6000 & Yes & No & No \\
\hline 35 & $\begin{array}{l}\text { Methanococcus } \\
\text { jannaschii }\end{array}$ & NA & 34 & 307 & NA & NA & No & $\mathrm{NA}$ & $\mathrm{NA}$ \\
\hline 36 & $\begin{array}{l}\text { Methanothrix } \\
\text { soehngenii }\end{array}$ & 33,35 & NA & NA & NA & 590 & Yes & No & No \\
\hline 37 & $\begin{array}{l}\text { Streptococcus } \\
\text { faecalis }\end{array}$ & 33 & NA & NA & 4 & 780 & Yes & No & No \\
\hline 38 & $\begin{array}{l}\text { Streptococcus } \\
\text { gordonii }\end{array}$ & NA & 34 & 311 & NA & NA & No & NA & NA \\
\hline
\end{tabular}

NA, No information available/given.

"References and comments: 1, Hachimori et al. (1975), Schreier \& Höhne (1978), Hachimori et al. (1979), Schreier (1980), Ichiba et al. (1990); 2, Shimizu et al. (1997); 3, Mitchell \& Minnick (1997); 4, Josse (1966), Wong et al. (1970), Lahti et al. (1988); 5, Fleischmann et al. (1995); 6, Tomb et al. (1997); 7, van Alebeek et al. (1994); 8, Fraser et al. (1995); 9, Himmelreich et al. (1996); 10, Meyer et al. (1995); 11, Richter \& Schäfer (1992a, b); 12, Kuranova et al. (1987), Höhne et al. (1988), Teplyakov et al. (1994); 13, Tominaga \& Mori (1977); 14, Kieber \& Signer (1991); 15, Volk et al. (1983), Lundin et al. (1991); 16, Hiraishi et al. (1997), heterodimer; 17, Yang \& Wensel (1992a, b); 18, Syiem \& Sharma (1996); 19, Thuillier (1978); 20, Stark \& Milner (1989); 21, Hachimori et al. (1983); 22, Felix \& Fleisch (1975); 23, du Jardin et al. (1995); 24, Morita \& Yasui (1978); 25, Mansurova (1989); 26, Mansurova (1989), heterodimer; 27, Irie et al. (1970), Yoshida et al. (1982); 28, Irie et al. (1970), Volk \& Baykov (1984), heterodimer; 29, Cooperman (1982), Kolakowski et al. (1988); 30, Lundin et al. (1991), 30 amino acid leader sequence not included; 31, Kawasaki et al. (1990); 32, Klenk et al. (1997); 33, Tono \& Kornberg (1967a), this paper; 34, Tono \& Kornberg (1967b), Kuhn \& Ward (1998); 35, Bult et al. (1996); 36, Jetten et al. (1992); 37, Lahti \& Niemi (1981); 38, Whittaker et al. (1996).

† In $\mu \mathrm{mol} \mathrm{PP}_{\mathrm{i}}$ hydrolysed $\mathrm{min}^{-1}$ (mg protein) $)^{-1}$.

bovine retina and porcine brain have specific activities approaching $1000 \mu \mathrm{mol} \mathrm{min}{ }^{-1}$ (mg protein $)^{-1}$, other activities are markedly lower than those of class A enzymes. This class of $\mathrm{PP}_{\mathrm{i}}$ ase appears the most variable, including smaller putative enzymes of Arabidopsis and potato, and the enzyme studied from human erythrocytes. Although, by itself, the deduced molecular mass of the potato enzyme might seem to place it in class A, nevertheless its sequence homology with that of Arabidopsis, together with its eukaryotic source, clearly places it in class $\mathrm{B}$.

Class $\mathrm{C} \mathrm{PP}_{\mathrm{i}}$ ases are the prokaryotic sequences recognized in B. subtilis, M. jannaschii, A. fulgidus and S. gordonii. Although identification of the latter three as $\mathrm{PP}_{\mathrm{i}}$ ases arises entirely from their sequence similarity with the $\mathrm{PP}_{\mathrm{i}}$ ase of $B$. subtilis, preliminary study (unpublished) of two of these species supports this prediction. These proteins differ from those of class $A$ and $B$ in their size (about 310 amino acids), and the $B$. subtilis enzyme has a strikingly greater specific activity. The $\mathrm{PP}_{\mathrm{i}}$ ase of $B$. megaterium has been included in this class on the basis of our unpublished studies on partially purified cell extracts, which show a $\mathrm{Mn}^{2+}$-activated enzyme obviously similar to that of the $B$. subtilis enzyme. It elutes similarly from columns of Sephacryl-
S200 as separate peaks of activated and deactivated form. SDS-PAGE reveals a band of mobility identical to that of $B$. subtilis $\mathrm{PP}_{\mathrm{i}}$ ase, with the $\mathrm{N}$-terminal sequence shown in Fig. 4. Even allowing for the lack of Nterminal methionine and the uncertain identification at two positions, the homology with the $B$. subtilis $\mathrm{PP}_{\mathrm{i}}$ ase is striking. The $\mathrm{PP}_{\mathrm{i}}$ ases of Streptococcus faecalis and Methanothrix soehngenii have been tentatively included in class $\mathrm{C}$ on the basis of their reported $33-35 \mathrm{kDa}$ subunit sizes (SDS-PAGE) that effectively exclude them from class A. Streptococcus pyogenes may also produce a class $C \mathrm{PP}_{\mathrm{i}}$ ase, judging from the significant similarity $\left(8 \cdot 1 \mathrm{e}^{-12}\right)$ with contig 238 of the database accessed at http://dna1.chem.uoknor.edu. It is premature to generalize about the subunit associations characteristic of this class.

The proposed classification of Table 2 interestingly rationalizes the variable fluoride sensitivity reported for different $\mathrm{PP}_{\mathrm{i}}$ ases. Simply put, class $\mathrm{A}$ and $\mathrm{B} \mathrm{PP}{ }_{\mathrm{i}}$ ases are strongly inhibited by about $1 \mathrm{mM}$ fluoride whereas class $\mathrm{CPP}_{\mathrm{i}}$ ases are not. In this context, Table 2 includes the briefly reported fluoride sensitivity of a bovine liver $\mathrm{PP}_{\mathrm{i}}$ ase, but excludes an accompanying fluoride-insensitive enzyme whose extremely low specific activity $\left[1 \mu \mathrm{mol} \mathrm{min}^{-1}\right.$ (mg protein) $\left.{ }^{-1}\right]$ renders its identity as a 
true $\mathrm{PP}_{\mathrm{i}}$ ase doubtful (Hiraishi et al., 1997). Detailed studies of yeast and rat liver $\mathrm{PP}_{\mathrm{i}}$ ases have shown the formation of stable enzyme-PP - -fluoride inhibition complexes also containing $2-4 \mathrm{Mg}^{2+}$ ions (Baykov et al., 1976, 1977, 1992). The implication that fluoride inhibition is a peculiarity of the active site fits with the apparent similarity of active sites in class A and B $\mathrm{PP}_{\mathrm{i}}$ ases and the apparent dissimilarity in class $C \mathrm{PP}_{\mathrm{i}}$ ases. According to Cooperman et al. (1992), 17 of about 24 residues conserved between class $\mathrm{A}$ and $\mathrm{B} \mathrm{PP}_{\mathrm{i}}$ ases are confined to a region in or close to the active site. As pointed out above, there are no obvious sequence similarities of $\mathrm{PP}_{\mathrm{i}}$ ases in these classes with those in class C. Less clear in Table 2 is the comparative sensitivity of $\mathrm{PP}_{\mathrm{i}}$ ases to thiol poisons. So far no such sensitivity has been found for class $\mathrm{C} \mathrm{PP}{ }_{\mathrm{i}}$ ases, whereas several class $\mathrm{A}$ and $\mathrm{B} \mathrm{PP}_{\mathrm{i}}$ ases are indeed sensitive. However the E. coli and $S$. cerevisiae $\mathrm{PP}_{\mathrm{i}}$ ases clearly show little sensitivity.

In conclusion, the present paper identifies an apparently new class of soluble $\mathrm{PP}_{\mathrm{i}}$ ase, already characterized in $B$. subtilis and $B$. megaterium but possibly also present in two archaea and a streptococcus. There may be two distinct evolutionary lines of $\mathrm{PP}_{\mathrm{i}}$ ase, both represented in prokaryotes but only one among eukaryotes.

\section{ACKNOWLEDGEMENTS}

We are grateful to Ross Edwards for skilled laboratory assistance.

\section{REFERENCES}

van Alebeek, G.-J., Keltjens, J. T. \& van der Drift, C. (1994). Purification and characterization of inorganic pyrophosphatase from Methanobacterium thermoautotrophicum. Biochim Biophys Acta 1206, 231-239.

Baykov, A. A., Artjukov, A. A. \& Avaeva, S. (1976). Fluoride inhibition of inorganic pyrophosphatase. I. Kinetic studies in a $\mathrm{Mg}^{2+}-\mathrm{PP}_{\mathrm{i}}$ system using a new continuous enzyme assay. Biochim Biophys Acta 429, 982-992.

Baykov, A. A., Bakuleva, N. P., Nazarova, T. I. \& Avaeva, S. M. (1977). Fluoride inhibition of inorganic pyrophosphatase. II. Isolation and characterization of a covalent intermediate between enzyme and entire substrate molecule. Biochim Biophys Acta 481, 184-194.

Baykov, A. A., Alexandrov, A. P. \& Smirnova, I. N. (1992). A twostep mechanism of fluoride inhibition of rat liver inorganic pyrophosphatase. Arch Biochem Biophys 294, 238-243.

Bradford, M. M. (1976). A rapid and sensitive method for the quantitation of microgram quantities of protein utilizing the principle of protein-dye binding. Anal Biochem 72, 248-254.

Bult, C. J., White, O., Olsen, G. J. \& 38 other authors (1996). Complete genome sequence of the methanogenic archaeon, Methanococcus jannaschii. Science 273, 1058-1073.

Chen, J., Brevet, A., Fromant, M., Leveque, F., Schmitter, J. M., Blanquet, S. \& Plateau, P. (1990). Pyrophosphatase is essential for growth of Escherichia coli. J Bacteriol 172, 5686-5689.

Cooperman, B. S. (1982). The mechanism of action of yeast inorganic pyrophosphatase. Methods Enzymol 87, 526-548.

Cooperman, B. S., Alexander, A. B. \& Lahti, R. (1992). Evolutionary conservation of the active site of soluble inorganic pyrophosphatase. Trends Biochem Sci 17, 262-266.
Felix, R. \& Fleisch, H. (1975). Properties of inorganic pyrophosphatase of pig scapula cartilage. Biochem J 147, 111-118.

Fleischmann, R. D., Adams, M. D., White, O. \& 37 other authors (1995). Whole-genome random sequencing and assembly of Haemophilus influenzae Rd. Science 269, 496-512.

Fraser, C. M., Gocayne, J. D., White, O. \& 26 other authors (1995). The minimal gene complement of Mycoplasma genitalium. Science 270, 397-403.

Fraser, C. M., Casjens, S., Huang, W. M. \& 35 other authors (1997). Genomic sequence of a Lyme disease spirochaete, Borrelia burgdorferi. Nature 390, 580-586.

Hachimori, A., Takeda, A., Kaibuchi, M., Ohkawara, N. \& Samejima, T. (1975). Purification and characterization of inorganic pyrophosphatase from B. stearothermophilus. J Biochem 77, 1177-1183.

Hachimori, A., Shiroya, Y., Hirato, A., Miyahara, T \& Samejima, T. (1979). Effects of divalent cations on thermophilic inorganic pyrophosphatase. J Biochem 86, 121-130.

Hachimori, A., Fujii, T., Ohki, K. \& lizuka, E. (1983). Purification and properties of inorganic pyrophosphatase from pig brain. $J$ Biochem 93, 257-264.

Himmelreich, R., Hilbert, H., Plagens, H., Pirkl, E., Li, B.-C. \& Herrmann, R. (1996). Complete sequence analysis of the genome of the bacterium Mycoplasma pneumoniae. Nucleic Acids Res 24, $4420-4449$.

Hiraishi, H., Ohmagari, T., Otsuka, Y., Yokori, F. \& Kumon, A. (1997). Purification and characterization of hepatic inorganic pyrophosphatase hydrolysing imidodiphosphate. Arch Biochem Biophys 341, 153-159.

Höhne, W. E., Wessner, H., Kuranova, I. \& Obmolova, G. V. (1988). Kinetic characterization of a thermostable inorganic pyrophosphatase from Thermus thermophilus. Biomed Biochim Acta 47, 941-947.

Ichiba, T., Takenaka, O., Samejima, T. \& Hachimori, A. (1990). Primary structure of the inorganic pyrophosphatase from thermophilic bacterium PS-3. J Biochem 108, 572-578.

Irie, M., Yabuta, A., Kimura, K., Shindo, Y. \& Tomita, K. (1970). Distribution and properties of alkaline pyrophosphatases of rat liver. J Biochem 67, 47-58.

du Jardin, P., Rojas-Beltran, J., Gebhardt, C. \& Brasseur, R. (1995). Molecular cloning and characterization of a soluble inorganic pyrophosphatase in potato. Plant Physiol 109, 853-860.

Jetten, M. S. M., Fluit, T. J., Stams, A. J. M. \& Zehnder, A. J. B. (1992). A fluoride-insensitive inorganic pyrophosphatase isolated from Methanothrix soehngenii. Arch Microbiol 157, 284-289.

Josse, J. (1966). Constitutive inorganic pyrophosphatase of Escherichia coli. I purification and catalytic properties. $J$ Biol Chem 241, 1938-1947.

Kawasaki, l., Adachi, N. \& Ikeda, H. (1990). Nucleotide sequence of Schizosaccharomyces. pombe inorganic pyrophosphatase. Nucleic Acids Res 18, 5888.

Kieber, J. J. \& Signer, E. R. (1991). Cloning and characterization of an inorganic pyrophosphatase gene from Arabidopsis thaliana. Plant Mol Biol 16, 345-348.

Klenk, H.-P., Clayton, R. A., Tomb, J.-F. \& 48 other authors (1997). The complete genome sequence of the hyperthermophilic, sulphate-reducing archaeon Archaeoglobus fulgidus. Nature 390, 364-370.

Kolakowski, L. F., Schloesser, M. \& Cooperman, B. S. (1988). Cloning, molecular characterization and chromosome localization of the inorganic pyrophosphatase (PPA) gene from Saccharomyces cerevisiae. Nucleic Acids Res 16, 10441-10452. 
Kuhn, N. J. \& Ward, S. (1998). Purification, properties, and multiple forms of a manganese-activated inorganic pyrophosphatase from Bacillus subtilis. Arch Biochem Biophys 354, 47-56.

Kunst, F., Ogasawara, N., Moszer, I. \& 148 other authors (1997). The complete genome sequence of the Gram-positive bacterium Bacillus subtilis. Nature 390, 249-256.

Kuranova, I. P., Obmolova, G. V. \& Konareva, N. V. (1987). Inorganic pyrophosphatase from the extremely thermophilic bacterium Thermus thermophilus HB8. Dokl Akad Nauk SSSR 295, 1013-1016.

Laemmli, U. K. (1970). Cleavage of structural proteins during the assembly of the head of bacteriophage T4. Nature 227, 680-685.

Lahti, R. \& Niemi, T. (1981). Purification and some properties of inorganic pyrophosphatase from Streptococcus faecalis. J Biochem 90, 79-85.

Lahti, R., Pitkaranta, T., Valve, E., Ilta, I., Kukko-Kalske, E. \& Heinonen, J. (1988). Cloning and characterization of the gene encoding inorganic pyrophosphatase of Escherichia coli K-12. J Bacteriol 170, 5901-5907.

Lundin, M., Baltscheffsky, H. \& Ronne, H. (1991). Yeast ppa2 gene encodes a mitochondrial inorganic pyrophosphatase that is essential for mitochondrial function. $J$ Biol Chem 266, 12168-12172.

Mansurova, S. E. (1989). Inorganic pyrophosphate in mitochondrial metabolism. Biochim Biophys Acta 977, 237-247.

Meyer, W., Moll, R., Th, K. \& Schäfer, G. (1995). Purification, cloning and sequencing of Archaebacterial pyrophosphatase from the extreme thermoacidophile Sulfolobus acidocaldarius. Arch Biochem Biophys 319, 149-156.

Mitchell, S. J. \& Minnick, M. F. (1997). Cloning, functional expression, and complementation analysis of an inorganic pyrophosphatase from Bartonella bacilliformis. Can J Microbiol 43, 734-743.

Morita, J. \& Yasui, T. (1978). Purification and some properties of a neutral muscle inorganic pyrophosphatase (rabbit skeletal). $J$ Biochem 83, 719-726.

Ogasawara, N., Nakai, S. \& Yoshikawa, H. (1994). Systematic sequencing of the 180 kilobase region of the B. subtilis chromosome containing the replication origin. DNA Res 1, 1-14.

Richter, O.-M. \& Schäfer, G. (1992a). Purification and enzymic characterization of the cytoplasmic pyrophosphatase from the thermoacidophilic archaebacterium Thermoplasma acidophilum. Eur J Biochem 209, 343-349.

Richter, O-M. \& Schäfer, G. (1992b). Cloning and sequencing of the gene for the cytoplasmic inorganic pyrophosphatase from the thermoacidophilic archaebacterium Thermoplasma acidophilum. Eur J Biochem 209, 351-355.

Sambrook, J., Fritsch, E. F. \& Maniatis, T. (1989). Molecular Cloning: a Laboratory Manual, 2nd edn. Cold Spring Harbor, NY: Cold Spring Harbor Laboratory.

Schreier, E. (1980). Reversible acid dissociation of thermostable inorganic pyrophosphatase from Bacillus stearothermophilus. FEBS Letts 109, 67-70.

Schreier, E. \& Höhne, W. E. (1978). Kinetic characterization of inorganic pyrophosphatase from Bacillus stearothermophilus. FEBS Letts 90, 93-96.

Shimizu, T., Imai, M., Araki, S., Kishida, K., Terasawa, Y. \& Hachimori, A. (1997). Some properties of inorganic pyrophosphatase from Bacillus subtilis. Int J Biochem Cell Biol 29, 303-310.
Stark, M. J. R. \& Milner, J. S. (1989). Cloning and analysis of the Kluyveromyces lactis TRP1 gene: a chromosomal locus flanked by genes encoding inorganic pyrophosphatase and histone $\mathrm{H} 3$. Yeast 5, 35-50.

Syiem, D. K. \& Sharma, R. (1996). Purification and kinetic characterization of chicken liver inorganic pyrophosphatase. Indian J Biochem Biophys 33, 363-370.

Teplyakov, A., Obmolova, G., Wilson, K. S., Ishii, K., Kaji, H. Samejima, T. \& Kuranova, I. (1994). Crystal structure of inorganic pyrophosphatease from Thermus thermophilus. Protein Sci 3 , 1098-1107.

Thompson, J. D., Higgins, D. G. \& Gibson, T. J. (1994). CLUSTAL w : improving the sensitivity of progressive multiple sequence alignment through sequence weighting, positions-specific gap penalties and weight matrix choice. Nucleic Acids Res 22, 4673-4680.

Thuillier, L. (1978). Purification and properties of human erythrocyte $\mathrm{Mg}^{2+}$-dependent inorganic pyrophosphatase. Biochim Biophys Acta 524, 198-206.

Tomb, J.-F., White, O., Kerlavage, A. R. \& 39 other authors (1997). The complete genome sequence of the gastric pathogen Helicobacter pylori. Nature 388, 539-547.

Tominaga, N. \& Mori, T. (1977). Purification and characterization of inorganic pyrophosphatase from Thiobacillus thiooxidans. $J$ Biochem 81, 477-483.

Tono, H. \& Kornberg, A. (1967a). Biochemical studies of bacterial sporulation. IV. Inorganic pyrophosphatase of vegetative cells and spores of Bacillus megaterium. J Bacteriol 93, 1819-1824.

Tono, H. \& Kornberg, A. (1967b). Biochemical studies of bacterial sporulation III. Inorganic pyrophosphatase of vegetative cells and spores of Bacillus subtilis. J Biol Chem 242, 2375-2382.

Volk, S. E. \& Baykov, A. A. (1984). Isolation and subunit composition of membrane inorganic pyrophosphatase from rat liver mitochondria. Biochim Biophys Acta 791, 198-204.

Volk, S. E., Baykov, A. A., Kostenko, E. B. \& Avaeva, S. M. (1983). Isolation, subunit structure and localization of inorganic pyrophosphatase of heart and liver mitochondria. Biochim Biophys Acta 744, 127-134.

Whittaker, C. J., Clemens, D. L. \& Kolenbrander, P. E. (1996). Insertional inactivation of an intrageneric coaggregation-relevant adhesin locus from Streptococcus gordonii DL1 (Challis). Infect Immun 4, 4137-4142.

Wong, S. C. K., Hall, D. C. \& Josse, J. (1970). Constitutive inorganic pyrophosphatase of Escherichia coli. III. Molecular weight and physical properties of the enzyme and its subunits. $J$ Biol Chem 245, 4335-4345.

Wurst, H., Shiba, T. \& Kornberg, A. (1995). The gene for a major exopolyphosphatase of Saccharomyces cerevisiae. J Bacteriol 177, 898-906.

Yang, Z. \& Wensel, T. G. (1992a). Inorganic pyrophosphatase from bovine retinal rod outer segments. J Biol Chem 267, 24634-24640.

Yang, Z. \& Wensel, T. G. (1992b). Molecular cloning and functional expression of $\mathrm{cDNA}$ encoding a mammalian inorganic pyrophosphatase. J Biol Chem 267, 24641-24647.

Yoshida, C., Shah, H. \& Weinhouse, S. (1982). Purification and properties of inorganic pyrophosphatase of rat liver and hepatoma 3924A. Cancer Res 42, 3526-3531.

Received 23 March 1998; revised 20 May 1998; accepted 1 June 1998. 